\title{
Effects of Core Banking System on Customer Satisfaction in Commercial Bank of Ethiopia
}

\author{
Melaku Tegafaw Bekele ${ }^{1} \quad$ Ayana Gemechu Bultum ${ }^{2}$ \\ 1 Ambo University,College of Business and Econmics,Department of Management \\ 2 Ambo University, College of Business and Economics, Department of Accounting \& Finance
}

\begin{abstract}
The use of core banking System in the various banks is drastically changing the way banking activities are being organized. Almost all banks in Ethiopia are in the process of transforming their banking systems to the modern technology in which they can offer efficient and globally competent services to their customers and get customers satisfaction in return. This study aimed to assess the effects of core banking system on customer satisfaction in commercial bank of Ethiopia. Stratified and convenient sampling techniques were used in the selection of each respondent from the commercial bank of Ethiopia. Conveniently 400 customers were selected and structured questionnaire and interview was used to collect relevant data for the research. The data gathered through the questionnaire was analyzed by using Statistical Package for Social Science (SPSS). The result of the study indicated that core banking information technology system indeed has a positive significance impact on customer satisfaction of commercial bank of Ethiopia. The Multiple linear regression analysis also showed a positive coefficient and adjusted $\mathrm{R}^{2}$ was $89.1 \%$, which simply mean that there is significant and strong positive relationship between core banking system and customers' satisfaction. In general, core banking Information Technology system has positively impacted on customer satisfaction of commercial bank of Ethiopia. Finally, it's suggested that commercial banks in Ethiopia needs to continue to explore and implement sustainable business linkages and collaborations with core banking system.
\end{abstract}

Keywords: Core banking system, customer satisfaction, Commercial Bank of Ethiopia, electronic service quality, electronic recovery service quality

DOI: $10.7176 / \mathrm{IKM} / 11-2-02$

Publication date:March $31^{\text {st }} 2021$

\section{Introduction}

Information and Communication Technology (ICT) is responsible for the change taking place globally. As a result of the prevailing advancement in information and communication technology, the banking industry worldwide is now operating in an unparalleled kind of competition backed up by modern information and communication system. (Bhaskar \& Tewodros, 2011)“Technology has opened up new markets, new products, new services and efficient delivery channels for the banking industry. Online electronic banking, mobile banking and internet banking are just few examples" (Dangolani, 2011, p.13).

Core banking system (CBS) has been effective in bringing about a radical change in the field of banking. CBS simplify their banking operations by allowing them to conduct common frequently used banking transactions without visiting bank's branches, saving a lot of time. CBS provides for online banking, Mobile banking and ATM services on 24/7 basis to customers so that a customer need not visit a bank for his banking needs (Biniyam \& Birhane, 2018).

In Ethiopia, the use of core banking IT System in the various banks is drastically changing the way banking activities are being organized. Almost all banks in Ethiopia are in the process of transforming their legacy banking systems to modern banking systems in which they can offer efficient and globally competent services to their customers and get customers satisfaction in return. Moreover, the National bank of Ethiopia has required all banks to implement core banking solutions to facilitate the National payment system in which payments and settlements between two financial institutions will be effective (EATS User Guide,2011).

Therefore this study aimed to examine the effect of core banking system implementation on customer satisfaction of commercial bank of Ethiopia.

\section{Review of Literature}

\subsection{Theoretical Review}

It is a well-established fact that individual user's preferences and beliefs impact on the performance or practice of almost every system. This review examines the parameter of effectiveness of CORE banking system in the customers" perspectives. Among so many different measuring parameters the following six parameters have been used more often than others in relation to CORE banking system and objectives of the research.

Flexibility: A flexible CORE banking system is a significant contributor to a bank's ability to respond quickly to changing market conditions (including compliance with changing regulations). Gartner Industry Research (2011) note stated, CORE banking solutions should provide flexibility that includes application connectivity and data 
integration, workflow, and components-based architectures.

Cost: Reducing costs are now basic expectations of CORE banking services. Some banks look at CORE banking from a cost savings point of view, as it is widely reported in ecommerce literature (Shah et al., 2007) that cost per transaction is much lower than for other service delivery channels.

Reliability: Reliability is an attribute of any computer-related component that consistently performs according to its specifications. It has long been considered one of three related attributes that must be considered when making, buying, or using a computer product or component. Similarly, Parasuraman et al. (1988) they have defined reliability as it is consistency of performance and dependability.

Speed: CORE banking makes transactions faster through dissemination of required information or data at a quicker and faster rate. The banking industry is currently being renewed in many areas. One of these areas related to the digitalization of formerly paper based processes. On the other hand, the introduction of ICT increases efficiency of the employee in the bank (Kulkarni K, Kalkundrikar S, 2002).

Assurance: According to (Gattiker, et. al.,2000), customers who adopt electronic services are more likely to perceive problems related to loss of privacy as the internet and other electronic tools seemingly allow other people to access their information easily. Therefore, it is assurance is a positive declaration intended to give confidence; a promise to secure individual or organization transaction and it is strong feeling of confidence about a given system.

Awareness: Socio-economic characteristics, personality variables and communication behavior all related to innovativeness. Innovativeness is the degree to which an individual or other adoption unit is relatively early in adopting new ideas compared to other members of a system (Roger, 1995; Ghamatrasa, 2006).

\subsection{Empirical Review}

Geetha \& Ramanarayanan (2013) study on the impact of Core Banking Services in SBM bank and clearly indicates that the customers were for the CBS because of its ease of operations, instantaneous, timely response and cost effectiveness. As CBS offers any time anywhere banking facility, customers are surely benefitted out of it and after the introduction of CBS the operational efficiency of banks has certainly improved.

Rono (2012) The purpose of his study was to: determine factors leading to replacement of core banking systems in commercial banks in Kenya; establish the challenges that commercial banks in Kenya encounter in the process of core banking systems replacement; and determine the effect of core banking systems replacement on bank performance and the Findings also indicated that replacing core systems has a significant positive effect on financial performance.

Hazraet.al. (2011) attempted to examine a contribution of various dimensions of service quality in customerse $^{\text {ee }}$ satisfaction. A result of the study indicates that, all 13 variables were found significant and were good predictors of overall satisfaction in e-banking. However, A result of principle component analysis indicates that, perceived value, brand perception, cost effectiveness, easy to use, convenience, problem handling, security/assurance and responsiveness are important factors in customers satisfaction in e-banking it explains 48.30 per cent of variance. Contact facilities, system availability, fulfillment, efficiency and compensation are comparatively less important because these dimensions explain 21.70 per cent of variance in customers e $^{\text {e }}$ satisfaction. Responsiveness, easy to use, cost effectiveness and compensation are predictors of brand perception in e-banking and fulfillment, efficiency, security/assurance, responsiveness, convenience, cost effectiveness, problem handling and compensation are predictors of perceived value in e-banking. Therefore, banker and ebanking service designers should think over these dimensions and make possible changes in the e-banking services according to the customers ${ }^{\text {ee }}$ expectations and need of the time. It will help to enhance service quality of e-banking and increase the level of customerse satisfaction in e-banking.

Baradaran et al. (2009) assessed the effect of using bank cards among the customers of Bank Melli in East Azerbaijan, and found that this usage can increase the customerse satisfaction and feeling of security (Coppin et al.2003) did a research with regard to all banks in Barbados and found that ATMs were not profitable at first, since training personnel and customers how to use them was expensive. But when it was educated, efficiency increased from $\% 3$ to $\% 17$.

Salman and Kashif (2010) study of electronic banking in Pakistan revealed that reliability, learning and feedback are very important for the satisfaction of the customers. This study also revealed those customers are not satisfied by the downloading time of website banks in Pakistan. If clients are not happy with the banking products, prices or services offered by a particular bank, they are able to change their banking partner much more easily than in the physical or real bank-client relationship.

Yalew, (2015) study the impact of information \& communication technology on Ethiopian private banks ${ }^{\text {ee }}$ performance he concluded that adoption of information and Communication Technology has a significant impact on customers ${ }^{\text {ee }}$ satisfaction. Furthermore, it can be deduced from the linear regression model that there is a strong positive relationship between adoption of Information and Communication technology and customers satisfaction. it can also be concluded that the impact of Information and Communication Technology on 
accuracy, problem handling process and complains resolving process of the banks was the least three among the factors affecting customers satisfaction In general, from the hypothesis tested, it can be concluded that adoption of information. Furthermore, it can be deduced from the linear regression that there was a strong relationship between adoption of Information and Communication.

Leyouager (2015) study the impact of e-banking in service quality and bank performance and the study conclude that ROE is not signified influence by electronic banking.

Eyob (2010) the study entitled "Capital Investment Decisions On IT And Its Impact On Corporate Value Maximization" has investigated the impact of IT on profitability and cost efficiency in six private commercial banks. He conclude that shown high IT capital did not result in a significantly better profit and cost performance compared to the relatively low IT capital banks. Milion (2013) He study presents what impact electronic banking has on customer satisfaction and Based on the result of the study he concluded that e-banking has impact in improving customer satisfaction, impact in reducing waiting time for customers to get bank service and impact in improving customers to control their account movements.

\subsection{CONCEPTUAL FRAMEWORK}

The study conceptual framework shows the relationship of core banking system on customer satisfaction of Commercial Bank of Ethiopia via E-S-Qual and E-Rec-S-Qual model and has been depicted as follows.

\section{In Dependent variable}

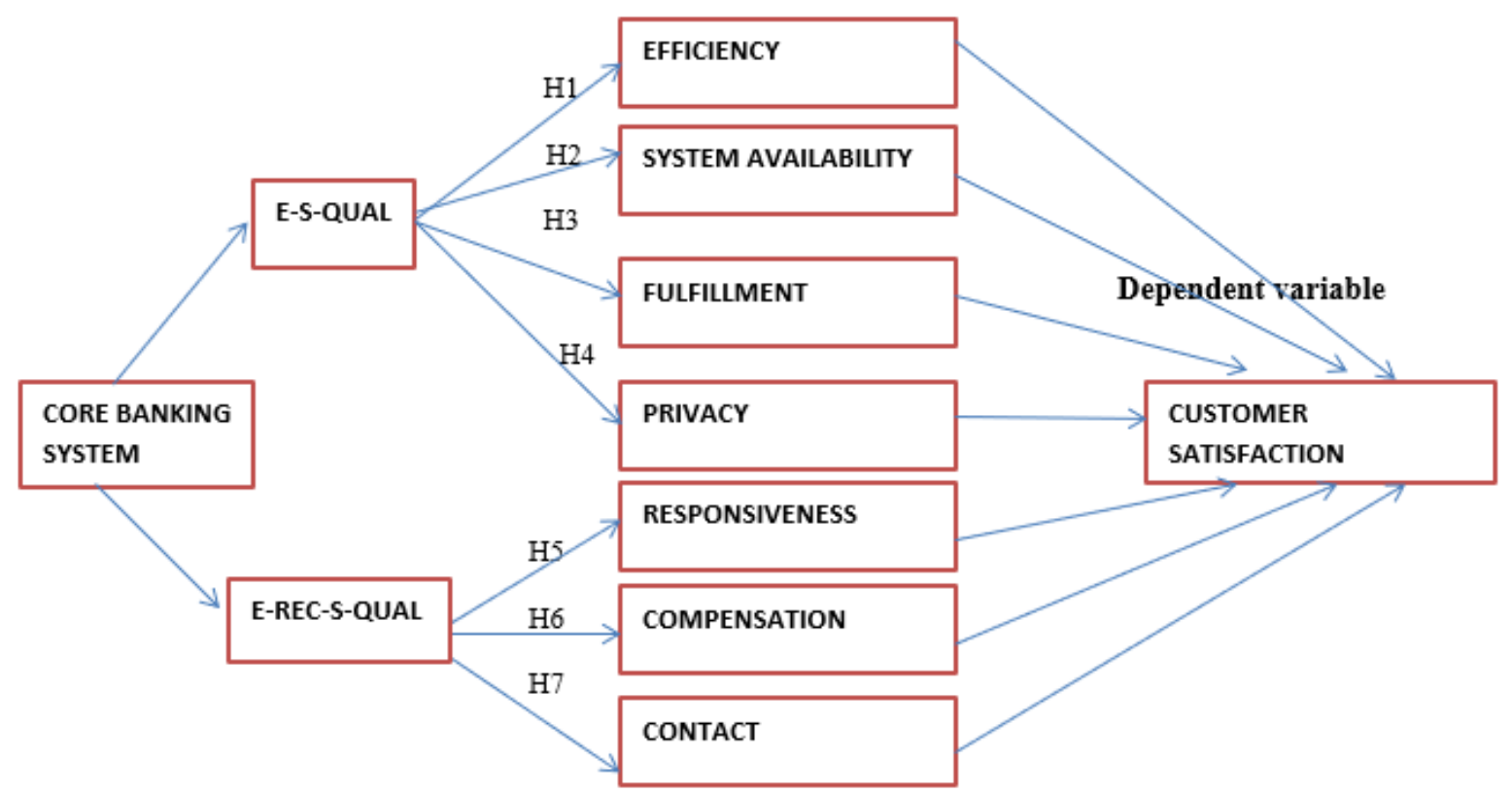

Source: Developed by researchers, 2020

\section{Materials and Methods}

Descriptive and explanatory type of research designs were used in this study. because the study able to describe the characteristics of the variables of interest in the existing situation and to describe relevant aspects of the phenomena of interest under study. The sample size was derived from the total population of 434,301,by using Yamane formula (1967) as follows

$$
=\frac{434,301}{1+434,301(0.05)^{2}}=400
$$

both primary and secondary sources of data were used. Primary data was collected from the respondents based on structurally designed questionnaires and structured interview with four branch managers. The study collect secondary data from the National Bank of Ethiopia and annual reports and examined different articles, academic journals, useful academic books and banks reports in order to strength the result and findings of the study as secondary data. (Kothari, 2004). Five point Likert scales which measure the effect of core banking information system on customer's satisfaction and the third part is open ended question. The customers are requested to express their level of agreement or disagreement with the statement. The variables were measured by using Likert scale with five response categories. (Strongly disagree, disagree, Neutral, agree and strongly agree).Both descriptive and inferential statistics were used for data analysis. 


\section{Model Specification}

Dependent variable: customer satisfaction denoted by "Y"

Independent variable: effect of CBS through four dimensions of E- S-Qual and three dimensions of E-Rec-SQual model

Regress customer satisfaction on the E- S-Qual and E-Rec-S-Qual dimensions

$\mathrm{Y}=\alpha+\beta 1 \mathrm{X} 1+\beta 2 \mathrm{X} 2+\beta 3 \mathrm{X} 3+\beta 4 \mathrm{X} 4+\beta 5 \mathrm{X} 5+\beta 6 \mathrm{X} 6+\beta 7 \mathrm{X} 7+\beta 8 \mathrm{X} 8$

Where $\mathrm{Y}$ is the dependent variable- customer satisfaction Efficiency $=\mathrm{X} 1$, System Availability $=\mathrm{X} 2$, Fulfillment $=\mathrm{X} 3$, Privacy $=\mathrm{X} 4$, Responsiveness $=\mathrm{X} 5$, Compensation $=\mathrm{X} 6$ and Contact $=\mathrm{X} 7$ are the explanatory variables (or the regresses).

\section{Results and Discussion}

\subsection{Descriptive Statistics Analysis}

Table 4.1 shows the Mean and standard deviation for core banking e-service quality and e-r- service quality Dimensions and Customer Satisfaction were depicted as follows:

\begin{tabular}{|l|l|l|l|}
\hline Dimensions & N & Mean & Std. Deviation \\
\hline EFFICIENCY & 400 & 3.93 & 1.111 \\
SYSTEM AVAILABLITY & 400 & 3.21 & 1.192 \\
FULFILLIMENT & 400 & 3.56 & 1.138 \\
PRIVACY & 400 & 3.89 & 1.139 \\
RESPONSIVNESS & 400 & 3.71 & 1.138 \\
COMPENSATION & 400 & 3.34 & 1.227 \\
CONTACT & 400 & 3.87 & 1.149 \\
CUSTOMER SATISFACTION & 400 & 4.13 & 1.108 \\
Valid N (listwise) & 400 & & \\
\hline
\end{tabular}

\section{Source: Survey Result, 2020}

Table 4.1 indicates that efficiency has the highest mean value and system availability have the least mean value. Therefore, it may be concluded from table 4.10 that respondents are most satisfied with efficiency (3.93), and followed by privacy dimensions with a mean and standard deviation of 3.89 and 1.139 respectively. Customers are less satisfied with system availability and compensation at a mean of, 3.21 and 3.34 respectively. Again, the above table depicts that general satisfaction towards core banking is very high with a mean of 4.13 and standard deviation of 1.108. The satisfaction has a mean score 4.13 which indicates that customers are satisfied with core banking of the bank electron service quality and electronic recovery service quality dimensions.

\subsection{PEARSON CORRELATION ANALYSIS}

To determine the relationship between core banking dimensions (efficiency, system availability, fulfillment, privacy, responsiveness, compensation, and contact) and customer satisfaction, below presents the results of Pearson correlation 
Table 4.2 correlations between CBS and customer satisfaction Correlations

\begin{tabular}{|l|l|r|}
\hline \multicolumn{2}{|l|}{} & CUSTOMER SATISFACTION \\
\hline \multirow{5}{*}{ EFFICIENCY } & Pearson Correlation & $.783^{* *}$ \\
\cline { 2 - 3 } & Sig. (2-tailed) & .000 \\
\cline { 2 - 3 } & $\mathrm{N}$ & 400 \\
\hline \multirow{5}{*}{ FUSTEM AVAILABLITY } & Pearson Correlation & $-.145^{* *}$ \\
\cline { 2 - 3 } & Sig. (2-tailed) & .004 \\
\cline { 2 - 3 } & $\mathrm{N}$ & 400 \\
\hline \multirow{5}{*}{ PRIVACY } & Pearson Correlation & $.824^{* *}$ \\
\cline { 2 - 3 } & Sig. (2-tailed) & .000 \\
\cline { 2 - 3 } & $\mathrm{N}$ & 400 \\
\hline \multirow{5}{*}{ RESPONSIVNESS } & Pearson Correlation & $.830^{* *}$ \\
\cline { 2 - 3 } & Sig. (2-tailed) & .000 \\
\cline { 2 - 3 } & $\mathrm{N}$ & 400 \\
\hline COMPENSATION & Pearson Correlation & $.714^{* *}$ \\
\cline { 2 - 3 } & Sig. (2-tailed) & .000 \\
\cline { 2 - 3 } & $\mathrm{N}$ & 400 \\
& Pearson Correlation & $.861^{* *}$ \\
\cline { 2 - 3 } & Sig. (2-tailed) & .000 \\
\cline { 2 - 3 } & $\mathrm{N}$ & 400 \\
\hline CONTACT & Pearson Correlation & $.262^{* *}$ \\
\cline { 2 - 3 } & Sig. (2-tailed) & .000 \\
\cline { 2 - 3 } & $\mathrm{N}$ & 400 \\
\hline CUSTOMER SATISFACTION & Pearson Correlation & 1 \\
\cline { 2 - 3 } & Sig. (2-tailed) & 400 \\
\cline { 2 - 3 } & $\mathrm{N}$ & \\
& &
\end{tabular}

**. Correlation is significant at the 0.01 level (2-tailed).

*. Correlation is significant at the 0.05 level (2-tailed).

Source: Survey Result, 2020

The results in table 4.2 indicate that, there is positive and significant relationship between all core banking e-service quality and e-r-service quality dimensions and customer satisfaction except system availability. Efficiency and customer satisfaction $(r=0.783, p<0.01)$, system availability and customer satisfaction $(r=$ $0.145, \mathrm{P}<0.01)$, fulfillment and customer satisfaction $(\mathrm{r}=0.824, \mathrm{P}<0.01)$, privacy and customer satisfaction ( $\mathrm{r}$ $=0.830, \mathrm{p}<0.01)$ responsiveness and customer satisfaction $(\mathrm{r}=0.714, \mathrm{P}<0.01)$, compensation and customer satisfaction $(\mathrm{r}=0.861, \mathrm{P}<0.01)$, contact and customer satisfaction $(\mathrm{r}=0.262, \mathrm{P}<0.01)$.

\subsection{MULTIPLE REGRESSION ANALYSIS}

Regression model was applied to test how far the core banking had effect on customer satisfaction. Coefficient of determination- $\mathrm{R}^{2}$ is the measure of proportion of the variance of dependent variable about its mean that is explained by the independent or predictor variables. Higher value of $\mathrm{R}^{2}$ represents greater explanatory power of the regression equation.

4.3.1 Effect of core banking on customer satisfaction Table 4.3 Regression model for core banking

Model Summary b

\begin{tabular}{|c|c|c|c|c|c|c|c|c|c|c|}
\hline \multirow[b]{2}{*}{ Model } & \multirow[b]{2}{*}{$\mathrm{R}$} & \multirow[b]{2}{*}{ R Square } & \multirow[b]{2}{*}{$\begin{array}{l}\text { Adjusted } \\
\text { R Square }\end{array}$} & \multirow{2}{*}{$\begin{array}{c}\text { Std. } \\
\text { Error of } \\
\text { the } \\
\text { Estimate }\end{array}$} & \multicolumn{5}{|c|}{ Change Statistics } & \multirow[b]{2}{*}{$\begin{array}{l}\text { Durbin- } \\
\text { Watson }\end{array}$} \\
\hline & & & & & $\begin{array}{c}\text { R Square } \\
\text { Change }\end{array}$ & $\begin{array}{c}\mathrm{F} \\
\text { Change }\end{array}$ & df1 & $\mathrm{df} 2$ & $\begin{array}{l}\text { Sig. F } \\
\text { Change }\end{array}$ & \\
\hline 1 & $.933^{\mathrm{a}}$ & .870 & .868 & .403 & .870 & 375.530 & $\overline{7}$ & 392 & .000 & .428 \\
\hline
\end{tabular}

a. Predictors: (Constant), CONTACT, EFFICIENCY, SYSTEM AVAILABLITY, RESPONSIVNESS, PRIVACY, FULFILLIMENT, COMPENSATION

b. Dependent Variable: CUSTOMER SATISFACTION

\section{Source: Survey Result, 2020}

The above table shows the $\mathrm{R}^{2}$ value of 0.870 . This result shows that the independent variable (core banking) accounted for 87 percent of the variance in customer satisfaction or the adjusted $\mathrm{R}^{2}$ of 0.868 indicates $87 \%$ of the variance in customer satisfaction can be predicted by the core banking system of the banks the other unexplored 
variables may explain the variation in customer satisfaction which accounts for 13 percent. Therefore, core banking system has a positive and significant effect on customer satisfaction. The tables also tell us DurbinWaston test which is 0.428 below 2 indicates positive autocorrelation in residuals (prediction error) from regression analysis.

Table 4.4 Regression model for Coefficients

\begin{tabular}{|c|c|c|c|c|c|c|c|}
\hline \multicolumn{8}{|c|}{ Coefficients $^{\text {a }}$} \\
\hline \multirow[b]{2}{*}{ Model } & \multicolumn{2}{|c|}{$\begin{array}{l}\text { Unstandardized } \\
\text { Coefficients }\end{array}$} & \multirow{2}{*}{$\begin{array}{c}\text { Standardized } \\
\text { Coefficients } \\
\text { Beta }\end{array}$} & \multirow[b]{2}{*}{$\mathrm{t}$} & \multirow[b]{2}{*}{ Sig. } & \multicolumn{2}{|c|}{$\begin{array}{l}95.0 \% \text { Confidence } \\
\text { Interval for B }\end{array}$} \\
\hline & $\mathrm{B}$ & $\begin{array}{l}\text { Std. } \\
\text { Error }\end{array}$ & & & & $\begin{array}{l}\text { Lower } \\
\text { Bound }\end{array}$ & $\begin{array}{l}\text { Upper } \\
\text { Bound }\end{array}$ \\
\hline 1 (Constant) & .457 & .123 & & 3.712 & .000 & .215 & .699 \\
\hline EFFICIENCY & .237 & .028 & .241 & 8.544 & .000 & .183 & .292 \\
\hline $\begin{array}{l}\text { SYSTEM } \\
\text { AVAILABLITY }\end{array}$ & -.057 & .018 & -.061 & -3.157 & .002 & -.092 & -.021 \\
\hline FULFILLIMENT & .217 & .033 & .223 & 6.619 & .000 & .153 & .282 \\
\hline PRIVACY & .203 & .033 & .209 & 6.096 & .000 & .137 & .268 \\
\hline RESPONSIVNESS & .098 & .027 & .105 & 3.633 & .000 & .045 & .152 \\
\hline COMPENSATION & .237 & .033 & .262 & 7.139 & .000 & .171 & .302 \\
\hline CONTACT & .056 & .019 & .059 & 2.884 & .004 & .018 & .094 \\
\hline
\end{tabular}

a. Dependent Variable: CUSTOMER SATISFACTION

Source: Survey Result,2020

The results of multiple regressions, as presented in table 4.4 above, efficiency has a positive and significant effect on customer satisfaction with a beta value (beta $=0.241)$, at 95 percent confidence level $(p<0.01)$. The results of table 4.13.also showed that the standardized coefficient beta and $p$ value of fulfillment were positive and significant (beta $=0.223, \mathrm{p}<0.01$ ). The results of table 4.4 also showed that the standardized coefficient beta and $p$ value of privacy were positive and significant (beta $=0.209, p<0.01$ ). The results also showed that the standardized coefficient beta and $p$ value of compensation were positive and significant (beta $=0.262, p<$ 0.01 ). Contact and responsiveness also positive and significant effect with beta value (beta $=0.059$, beta $=0.105$ $\mathrm{p}<0.01$ ) respectively. As shown in table 4.13 the only system availability has no positive and significant effect on customer satisfaction with the beta value of (beta $=-0.061, p<0.01$ ) the equation of the research regression model is:

\section{$Y=0.457+0.237 X_{1}-0.057 X_{2}+0.217 X_{3}+0.203 X_{4}+0.098 X_{5}+0.237 X_{6}+0.056 X_{7}$}

\subsubsection{Multicollinearity Test}

Table 4.14 multicollinearity test

\begin{tabular}{|c|c|c|c|c|c|c|c|c|c|}
\hline \multirow[b]{3}{*}{ Model } & \multicolumn{7}{|c|}{ Coefficients $^{\text {a }}$} & & \\
\hline & \multicolumn{2}{|c|}{$\begin{array}{c}\text { Unstandardized } \\
\text { Coefficients }\end{array}$} & \multirow{2}{*}{$\begin{array}{c}\text { Standardized } \\
\text { Coefficients } \\
\text { Beta }\end{array}$} & \multirow[b]{2}{*}{$\mathrm{t}$} & \multirow[b]{2}{*}{ Sig. } & \multicolumn{2}{|c|}{$\begin{array}{c}95.0 \% \\
\text { Confidence } \\
\text { Interval for B }\end{array}$} & \multicolumn{2}{|c|}{$\begin{array}{c}\text { Collinearity } \\
\text { Statistics } \\
\end{array}$} \\
\hline & $\mathrm{B}$ & $\begin{array}{l}\text { Std. } \\
\text { Error }\end{array}$ & & & & $\begin{array}{l}\text { Lower } \\
\text { Bound }\end{array}$ & $\begin{array}{l}\text { Upper } \\
\text { Bound }\end{array}$ & Tolerance & VIF \\
\hline 1 (Constant) & .457 & .123 & & 3.712 & .000 & .215 & .699 & & \\
\hline EFFICIENCY & .237 & .028 & .241 & 8.544 & .000 & .183 & .292 & .416 & 2.406 \\
\hline $\begin{array}{l}\text { SYSTEM } \\
\text { AVAILABLITY }\end{array}$ & -.057 & .018 & -.061 & -3.157 & .002 & -.092 & -.021 & .884 & 1.132 \\
\hline FULFILLIMENT & .217 & .033 & .223 & 6.619 & .000 & .153 & .282 & .291 & 3.431 \\
\hline PRIVACY & .203 & .033 & .209 & 6.096 & .000 & .137 & .268 & .283 & 3.535 \\
\hline RESPONSIVNESS & .098 & .027 & .105 & 3.633 & .000 & .045 & .152 & .398 & 2.512 \\
\hline COMPENSATION & .237 & .033 & .262 & 7.139 & .000 & .171 & .302 & .246 & 4.073 \\
\hline CONTACT & .056 & .019 & .059 & 2.884 & .004 & .018 & .094 & .792 & 1.263 \\
\hline
\end{tabular}

a. Dependent Variable: CUSTOMER SATISFACTION

Source: own survey, 2019

An important assumption for the multiple regression models is that independent variables are not perfectly multicolinear. Multicollinearity refers to the situation in which the independent/predictor variables are highly correlated. When independent variables are multicollinear, there is "overlap" or sharing of predictive power. 
The easiest way to measure the extent of multicollinearity is simply to look at the Collinearity Statistics. These are Tolerance and variance inflation factor (VIF). Hence, very small values indicate "overlap" or sharing of predictive power (i.e., the predictor is redundant). the tolerance Values that are less than 0.10 may merit further investigation. The VIF is computed as "1/tolerance," and it is suggested that predictor variables whose VIF values are greater than 10 may merit further investigation (G. David, 2012). Then the regression model is not need to worry about multicollinearity because the predictor variables whose Tolerance are greater than 0.1 and predictor variables whose VIF value are less than 10

\subsubsection{Analysis of variance (ANOVA)}

Table 4.15 ANOVA

\begin{tabular}{|rl|r|r|r|r|r|}
\hline Model & & ANOVA & & \multicolumn{1}{c|}{ a } & Sig. \\
\hline \multirow{2}{*}{1} & Regression & Sum of Squares & df & Mean Square & F & $.000^{\text {b }}$ \\
& Residual & 426.393 & 7 & 60.913 & 375.530 & \\
& Total & 63.585 & 392 & .162 & & \\
\hline
\end{tabular}

a. Dependent Variable: CUSTOMER SATISFACTION

b. Predictors: (Constant), CONTACT, EFFICIENCY, SYSTEM AVAILABLITY, RESPONSIVNESS, PRIVACY, FULFILLIMENT, COMPENSATION

Source: own survey, 2019

The above ANOVA table displayed the probability level of significance value of 0.000 .therefore the probability(0.000)is much smaller than 0.05 , then multiple regression model can be used to predict the customer satisfaction. Or all independent variables of this research are significant effect on customer satisfaction.

\subsubsection{Normality Test}

In order to make valid inferences from this regression, the residuals of the regression should follow a normal distribution. The residuals are simply the error terms, or the differences between the observed value of the dependent variable and the predicted value. If we examine a normal Predicted Probability (P-P) plot, we can determine if the residuals are normally distributed. So the following Predicted Probability (P-P) plot, histogram and scatterplot conform to the diagonal normality line indicated in the plot.

Table 4.16 Normality test

Residuals Statistics ${ }^{\text {a }}$

\begin{tabular}{|l|r|r|r|r|r|}
\hline & \multicolumn{1}{|c|}{ Minimum } & Maximum & Mean & Std. Deviation & $\mathrm{N}$ \\
\hline Predicted Value & 1.33 & 5.53 & 4.13 & 1.034 & 400 \\
Residual & -1.315 & 1.579 & .000 & .399 & 400 \\
Std. Predicted Value & -2.706 & 1.352 & .000 & 1.000 & 400 \\
Std. Residual & -3.264 & 3.921 & .000 & .991 & 400 \\
\hline
\end{tabular}

a. Dependent Variable: CUSTOMER SATISFACTION

Source: own survey, 2019 


\section{Charts}

\section{Histogram}

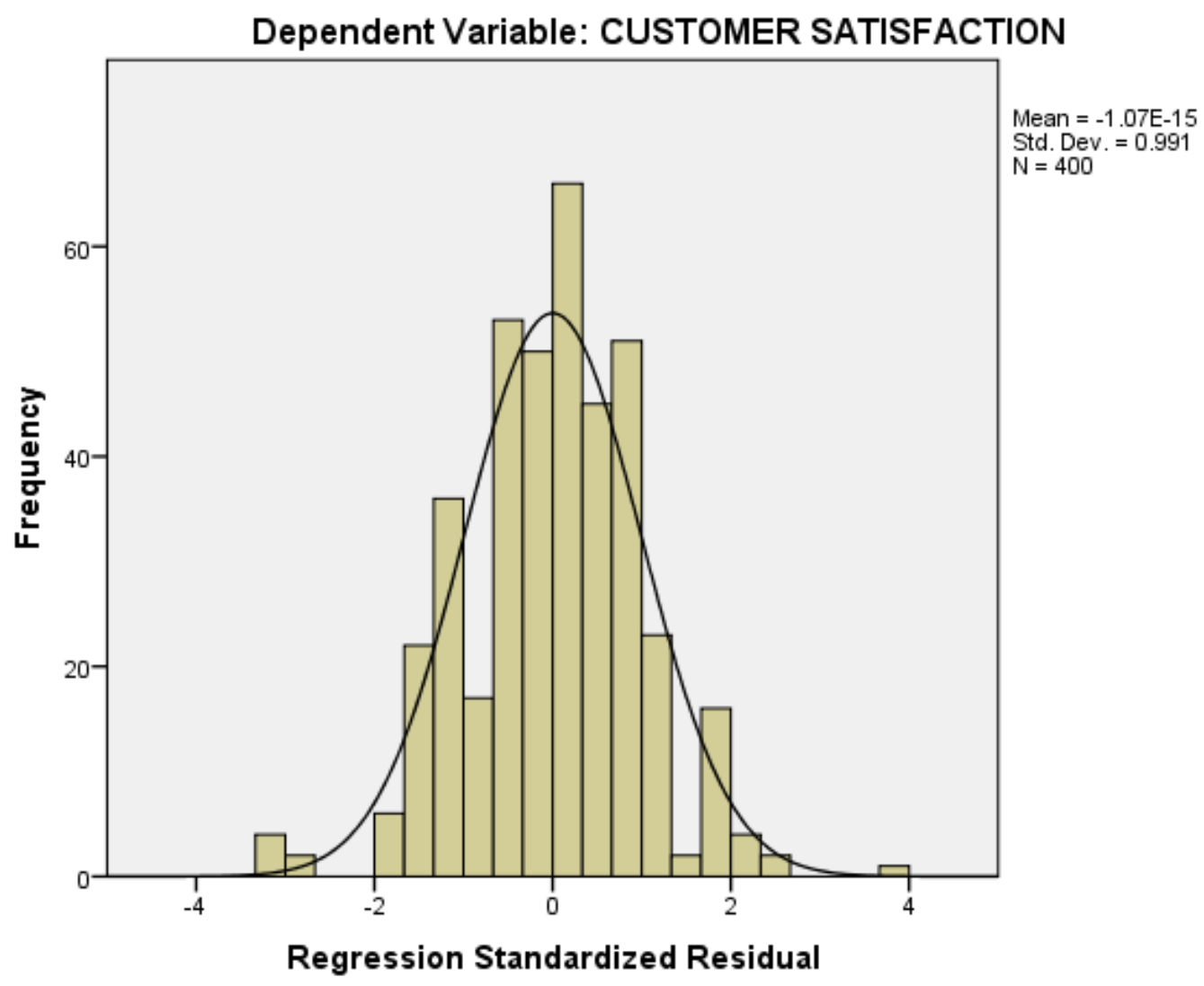

Figure 1 Histogram

Chebyshev's theorem applies to any distribution regardless of its shape. However, when

The above histogram distribution is bell-shaped so that, this regression is normal distribution. (Bluman, 2012) 


\section{Normal P-P Plot of Regression Standardized Residual}

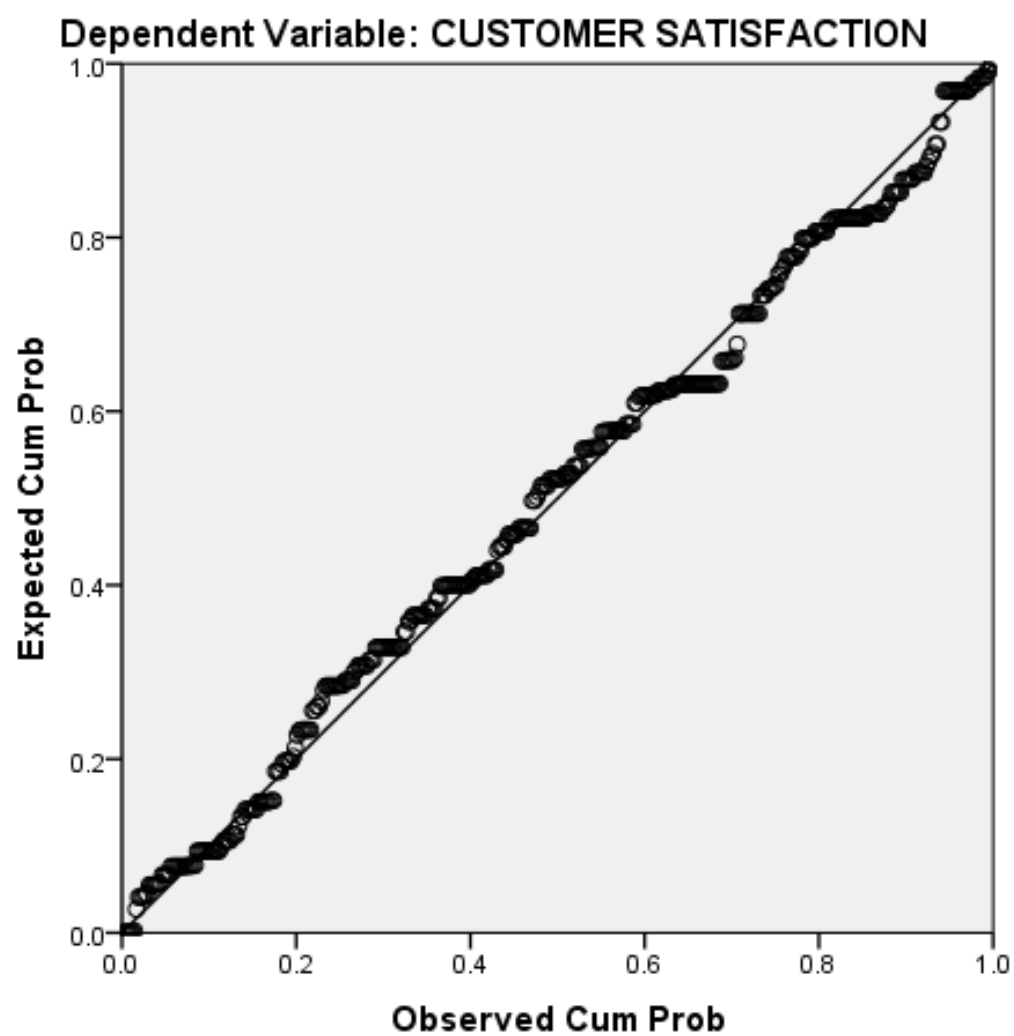

Figure 2 Normal P-P Plot of Regression

The plot shows that the points generally follow the normal (diagonal) line with no strong deviation this indicates that the residual are normally distributed.

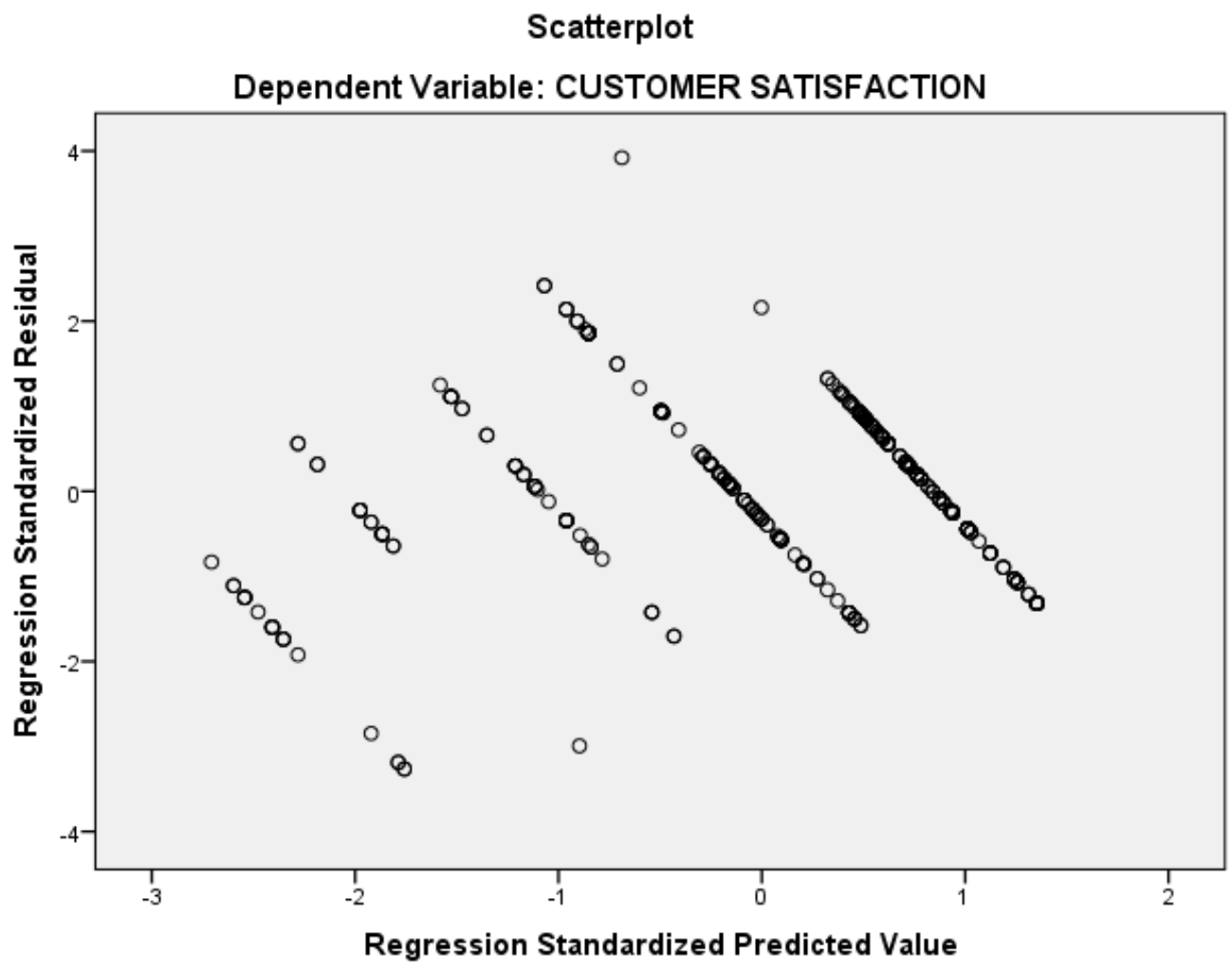

Figure 3 Scatterplot 


\subsection{HYPOTHESIS TESTING}

Hypothesis testing is based on standardized coefficients beta with $95 \%$ confidence level to test whether the hypotheses are rejected or not.

\section{Hypothesis 1}

Ho1: CBS Efficiency has a significant positive association with on Customer Satisfaction

Ha1: There is a positive relationship between CBS efficiency and customer satisfaction in banking services. The results of multiple regressions, as presented in table 4.13.above, revealed that CBS Efficiency have a positive and significant effect on customer satisfaction with a standardize coefficient beta value, (.241), at $95 \%$ confidence level. Therefore, the study may accept the null hypothesis. Since, CBS efficiency has a positive and significant effect on customer satisfaction.

\section{Hypothesis 2}

Ho2: CBS availability has a significant positive association with Customer Satisfaction

$\mathrm{Ha} 2$ : There is a negative relationship between CBS system availability and customer satisfaction in banking services. The results of multiple regressions, as presented in table 4.13.above, revealed that CBS system availability have a negative and insignificant effect on customer satisfaction with a standardize coefficient beta value, (-.061), at 95\% confidence level. Therefore, the study may reject the null hypothesis. Since, CBS system availability has a negative and insignificant effect on customer satisfaction.

\section{Hypothesis 3}

H3: CBS Fulfillment has a significant and positive association with Customer Satisfaction

Ha3: There is a positive relationship between CBS Fulfillment and customer satisfaction in banking services. The results of multiple regressions, as presented in table 4.13.above, revealed that CBS Fulfillment have a positive and significant effect on customer satisfaction with a standardize coefficient beta value, (.223), at $95 \%$ confidence level. Therefore, the research may accept the null hypothesis. Since, CBS Fulfillment has a positive and significant effect on customer satisfaction.

\section{Hypothesis 4}

Ho4: CBS Privacy has a significant positive association with Customer Satisfaction

Ha4: There is a positive relationship between CBS Privacy and customer satisfaction in banking services. The results of multiple regressions, as presented in table 4.13.above, revealed that CBS Privacy have a positive and significant effect on customer satisfaction with a standardize coefficient beta value, (.209), at 95\% confidence level. Therefore, the research may accept the null hypothesis. Since, CBS Privacy has a positive and significant effect on customer satisfaction.

\section{Hypothesis 5}

Ho5: CBS Responsiveness has a significant positive association with. Customer Satisfaction

Ha5: There is a negative relationship between CBS Responsiveness and customer satisfaction in banking services. The results of multiple regressions, as presented in table 4.13.above, revealed that CBS Responsiveness have a positive and significant effect on customer satisfaction with a standardize coefficient beta value, (.105), at $95 \%$ confidence level. Therefore, the research may accept the null hypothesis. Since, CBS Responsiveness has a positive and significant effect on customer satisfaction.

\section{Hypothesis 6}

Ho6: CBS Compensation has a significant positive association with. Customer Satisfaction

Ha6: There is a positive relationship between CBS Compensation and customer satisfaction in banking services. The results of multiple regressions, as presented in table 4.13.above, revealed that CBS Compensation have a positive and significant effect on customer satisfaction with a standardize coefficient beta value, (.262), at 95\% confidence level. Therefore, the research may accept the null hypothesis. Since, CBS Compensation has a positive and significant effect on customer satisfaction.

\section{Hypothesis 7}

Ho7: CBS Contact has a significant positive association with Customer Satisfaction

Ha7: There is a positive relationship between CBS Contact and customer satisfaction in banking services. The results of multiple regressions, as presented in table 4.13.above, revealed that CBS Contact have a positive and significant effect on customer satisfaction with a standardize coefficient beta value, (.059), at $95 \%$ confidence level. Therefore, the research may accept the null hypothesis. Since, CBS Contact has a positive and significant effect on customer satisfaction.

\subsection{Analysis of Open Ended Question}

Majority of the respondent states their opinion regarding core banking service. From their suggestion it can be inferred that network problem is the big issues. The network problem is the major obstacle in the check clearing operations, quick transfer of fund, cash withdrawal and etc. In addition, the temporary failures in core banking services are not corrected immediately. 


\subsection{Analysis of Interview Question}

The selected branch managers were said that in the present day the most famous, influential and the biggest banks in the world have been used core banking system. This CBS enables the customer to transact or perform all banking services / products at any time ever where with faster rate. Additionally CBS plays an important role to move forward the country economy, create cashless society, to improve the productivity of employees, to perform all the bank activities with integrated way and with less effort, its efficient and effective at every aspect. They also say" that but in our country Ethiopia to adopted the CBS is faced by, obstacles and some bottlenecks challenges like IT infrastructure, Network problem till monopolized by ethio telecom, electric power interruption, lack of skilled manpower, shortage of capital to facilitate some materials etc.".

They said that" the coming day will bright bit by bit, bridge by bridge every vicious circle will be broken, the problem will solve".

So that the CBS plays an important role to day that is enables to CBE to retain the existing customers and attract the external environment and recruit the new customer. The base of CBE is customers the satisfaction reasons of customers are core banking system.

However core banking system and customer satisfaction are one coin two face higher customer satisfaction rates is the result of the proper adaptation and working core banking system. In order to create loyal customer and achieving CBEs vision "to become world class commercial bank by the year 2025" core banking system and satisfied and loyal customer plays an important role.

\section{Conclusions}

The study was conducted to examine the effect of the application of core banking on customer satisfaction selected branch. The finding of the study indicates that customers of bank were satisfied by core banking. The finding of the study also indicates that, customers were most satisfied with the efficiency of core banking system dimensions of e-service quality. However, customers were less satisfied system availability core banking system dimensions of e-service quality. The correlation result shows that, core banking system dimensions (E- S-QUAL and E-REC-S-QUAL) are positively and significantly related with customer satisfaction.

Unlike system availability the sixth core banking system E- S-QUAL and E-REC-S-QUAL dimensions including efficiency, fulfillment, privacy, responsiveness, compensation and contact have positive and significant impact on customer satisfaction. The findings of this study also indicated that efficiency is the most important factor to have a positive and significant impact on customer satisfaction. In addition to this, except system availability the sixth core banking system E- S-QUAL and E-REC-S-QUAL dimensions significantly explain the variations in customer satisfaction.

However the study indicates that, customers are satisfied by core banking system of the bank. From the finding of this study it is possible to concludes that core banking system has positive and significant relationship with customer satisfaction. And also core banking system has positive and significant effect on customer satisfaction.

\section{References}

Abebe, E. (2013). Assessing the impact of Core Banking and service quality on Customer Hawassa University

Adewoye, J. (2007). Impact of IT investment on banking operations in Nigeria international business management, $70-78$

Ahmad, J. C. (2013). Factors Affecting on Customer Satisfaction in Retail Banking: An Empirical Study. International journal of Business and Management Invention (ISSN (Online), vol. 2, Issue 1, 2319-8028

Akınc1, S., Atılgan-İnan, E. \&Aksoy, Ș. (2010). Re-assessment of E-S-Qual and ERecS-Qual in a pure service setting, Journal of Business Research, 63, pp. 232-240

Bhaskar, R. \&Tewodros, S. (2011). E-Business: application of software \& technology in selected Ethiopian banks: issues and challenges. International journal of computer science. Volume 8, issue 6, no. 1, pp. 190198

BelayG.(1987).Currencyandbanking:Ethiopia.fromhttp://www.ethiopianreview.com/archive/164 095842808211102_ethiopia.html.

Berry LL, Z. V. (1990). Five imperatives for improving service quality. Sloan Manage Rev, 31(4): 29-38.

Beyene,t. t. (2014). Assessment of Core Banking System adoption in awash international bank. SMU

Biju, K. Devandhiran, D. \&Sreehari, R. (2012).Customers' satisfaction on core banking: A study with special reference to a nationalized bank in THIRUNELVELI. ijrcm- 1 - vol-3, pdfavailable at http://www.ijrcm.org.in/download.php?name=

BiniyamGetneta and BirhaneNanob(2018) Assessing the impact of Core Banking and service quality on Customer Satisfaction: Case of the Commercial Bank of Ethiopia in Bale Robe Town

Bluman, Allan G.(2012) Elementary statistics : a step by step approach / Allan Bluman. - 8th ed. p. cm. Community College of Allegheny County 
Chairlone, S. G. (2009). Emerging Banking Systems Palgrave Macmillan, London

Commercial Bank of Ethiopia web page https://www.combanketh.et

Dandapani K. (2008). Internet banking services and credit union performance Managerial Finance, Vol. 34, No. 6, PP. 437-446.

Dangolani, SaeidKhajeh (2011). The Impact of Information Technology in Banking System (A Case Study in Bank Keshavarzi IRAN).Procedia - Social and Behavioral Sciences, 30, 13 - 16

Ethiopia, N. B. (Ethiopia). A PARTICIPANT EATS User Guide v 1.0. 2011

Eyob (2010) Capital Investment Decisions On IT And Its Impact On Corporate Value Maximization

Field, A. (2009). Discovering statistics using SPSS (3rd edition ed.). SAGE

G. David Garson (2012) Testing statistical assumption Blue book series North Carolina state university

Geetha, C. S. (2015). The impact of Core Banking Services in SBM International Journal of Commerce Business and Management

Gartner Industry Research Note. Core Banking System Selection: Criteria that Matter.Don Free, 27 April 2011.

Gattiker UE, Perlusz S, Bohmann K. Using the Internet for B2B activities: a review and future directions for research. Internet research: Electronic Networking Applications and policy 2012; 10(2): $126-40$.

IBM, F. S. (2011). Core Banking Modernization

Israaawadallah Mustafa, s. a. (june 2013). Investigation of core banking System University of Khartoum Sudan

Jalulah, A. M. (2011). Evaluation of Customer Satisfaction with Internet Banking Service Quality in the Banking Industry in Ghana MSC Thesis Lulea University of Technology Ghana

Jensen, M. C. (2001). Value maximization \& corporate objective function. working paper Harvard business school, pp2.

k. Hoffman and Batteson. (2011). Service Marketing concepts, starategies and cases .Mason, OH 45040 USA: South-Western, a part of Cengage Learning.

Kaur R. (2012). Impact of information technology on customer service with reference to selected banks in chandigarh. International journal of engineering and management science vol.3 (4), 2012: 444-449.

Kotler, P and Keller, K. L. (2009) Marketing ManagementNew Jersey: Pearson Education Inc.

Kulkarni K, Kalkundrikar S (2012). Monetary Economics, Banking and International Trade R. Chand and Co. Publishers New Delhi

Kumbhar, V. M. (2012). Alternative Banking Channels and Customers" Satisfaction: An Empirical Study of Public and Private Sector Banks. International Journal of Business and Management Tomorrow, Vol. 1 No. 1

Levesque T and McDougall G H C (1996), Determinants of Customer Satisfaction in Retail Banking International Journal of Bank Marketing, 14(7), 12-

Leyouager (2015) the impact of e-banking in service quality and bank performance and the study conclude that $R O E$ is not signified influence by electronic banking

M.K. V. (n.d.). Factors affecting customer satisfaction in E-Banking

Maleki,M. \&Akbari. (2010). Investigating the role of electronic banking in Iran. Journal of Bank and Economics, issue 112, pp. 14-20

Muhammad Imran Qureshi, A. R. (2013). Factors influencingcustomer Satisfaction in banking sector of Pakistan.http://www.sciencepub.net/ report, Report and opinion (5(2)

Negash, z. (2014) Effect of e-banking service on banking profitability in Ethiopian SMU

Nigussie, Y. (2015). The impact of information \& communication technology on Ethiopian private banks" performance: the case of two selected Ethiopian private banks. AAU

Oliver, R. (1997). Satisfaction: A Behavioral Perspective on the Consumer. New York: McGraw Hill.

Ombati, T. P. (2010). Technology and Service Quality in the Banking Industry African Journal of Business and Management

Parasuraman A, Zeitham VA, Berry LL. SERVQUAL: A multiple-item scale for measuring consumer perceptions of service quality. Journal of Retailing 1988; 64(1): 12-40.

Rhoades, S. (1998). The Efficiency Effects of Bank Mergers: an overview of case studies. Journal of Banking and Finance, vol 22, no 3, March, pp 273-91

Rogers EM Diffusion of Innovation (4th ed.), New York: The Free Press, 1995.

Rono, w. k. (November 2012). Core Banking Systems Replacement and Performance in Commercial Banks in Kenya University of Nairobi

Salman and Kashif (2010) electronic banking in Pakistan revealed that on reliability

Shah H Braganza A, Morabito V. A Surveyof Critical Success Factors in e-Banking: An Organizational Perspective. European Journal of Information Systems 2007; 16(4): 511-524.

Siam, A. Z. (2006). Role of the electronic banking services on the profits of Jordanian banks. American Journal of Applied Sciences

Zeithaml, V. P. (2000). A Conceptual Framework For Understanding E-Service Quality: Implications For 
Future Research And Managerial Practice. Working Paper, Report No. 00-115 Marketing Science Institute, Cambridge, MA.

Zelthmal A \&Bitner M. (2006) Service Marketing -Integrating Customer Focus 3rd editionNew Delhi: Tata MacGraw-Hill. Publishing Company Limited. 